\title{
A Needs Analysis for The Improvement of The Students' Communicative Competence; a Syllabus Design for Speaking 1 Course at English Department Sawerigading University
}

\author{
Syamsuddin, Jamaluddin Al Afgani \\ English Department, Faculty of Letters \\ Sawerigading University, Makassar, Indonesia \\ Email : british.sam@gmail.com
}

\begin{abstract}
Each learner has different needs in learning, as well as the students at the English Department Sawerigading University Makassar. This study aims at determining the effectiveness of a needs analysis to design a syllabus for the speaking 1 course to enhance the students' communicative competence. Research and Development Method (R\&D) is used with three systematic steps: input, development, and output. The input step begins with a needs analysis (NA) involving 40 respondents who are chosen purposively. The data are collected through NA questionnaires and they are analyzed descriptively. Development Step is made to formulate the objectives and course targets that are then used to determine the course subject of speaking 1 . The output step is done to design lesson plans and prototype of teaching materials. This study has found a teaching material development methodology that has resulted lesson plans and prototypes for a unit of instruction-based resource needs. This methodology can be used by designers or lecturers to develop other English teaching materials in various courses.
\end{abstract}

Keywords: Lesson plans, needs analysis, speaking 1 course, syllabus, teaching materials

\section{INTRODUCTION}

Each learner has different needs in his/her learning, as well as the students of the English language and literature study program of Sawerigading University Makassar. Formally, they have learned English from grade 4 elementary school (SD) to third grade in senior high school (SMA) and continued again at college. That means that they have been learning English for about 8 years. However, their complaints regarding their very low English proficiency have not been answered, although they are currently majoring in English Department at college. This issue not only happens in the English department of Sawerigading University, but this also happens in other universities.

All this time, there have been some researches carried out on college students' low English proficiency in Indonesia. For instance, Lowenberg 
(1991) has reported that some factors might contribute to the problem of the low level of English proficiency encountered by students learning English. The first factor is the problem within the curriculum and syllabus. The second one is the Indonesian classroom situation which is still generally overcrowded and noisy. The third factor is that there are many teachers who are still lacking in proficiency in English or still need more training in language pedagogy. In addition, Alwasilah (2007) also has found some weaknesses in the English courses at the college level that make the students' communicative competence low: (1). No needs analysis conducted to find that the course does not meet the students' expectations. (2). The entrance levels of the students in the class are relatively heterogeneous. (3). The course is taught by inexperienced teachers. (4). There is repetition of what has been taught at secondary schools. (5). There is no selection and classification based on competencies and students' needs. (6). There is no coordination among intra-and interinstitutions. As a final point, we can at least identify three major causal problems of the college students' low English communicative competence i.e. the first: problems associated with curriculum and syllabus which are designed without needs analysis, the second: problems related to the overcrowded classrooms, and the third: problems associated with unqualified teachers.

As a response to the reports, this research investigates how to develop a well-designed English teaching material on the basis of a needs analysis as an effort to improve English learning outcomes in college level. In many colleges, teaching materials have been developed without any needs analysis at all. They are mostly developed based on the teachers' perceptions, intuitions, as well as subjective personal belief without any objective assessments of the learners' situations and needs. Consequently, the teaching materials do not reliably ensure that the course contents are appropriate, effective, practical, and realistic to enable the students succeed in mastering English. Paradowski (2002) considers that the first step of every syllabus design should be needs analysis, i.e. a set of techniques and procedures used for obtaining information about the learners and situations and purposes for which they want to learn the language. Therefore, to determine what the students need to achieve through the medium of teaching them English skills e.g. speaking, it is very important to carry out the needs analysis before designing the course syllabus and developing the course teaching materials. With regard to the statement, Richards (2001) mentions that different types of students have different language needs and what they are taught should be restricted to what they need. Similarly, Engelmann (1993) states that the curriculum applied by the teachers in the classroom interaction must be relevant to the students' needs.

As a result, this study finds a comprehensive framework for necessary steps of needs analysisbased materials development which has been used for developing English teaching materials for speaking 1 course. Using the framework has resulted in a prototype for one unit of the course. We believe that the framework can be used as a guideline by designers or English teachers for developing the teaching materials for other units and for producing well-developed English teaching materials for other courses.

\section{METHODOLOGY PARTICIPANTS}

There were 40 participants purposively chosen in this study. They consisted of 29 students who took speaking 1 course in the first semester of academic year 2017/2018, 5 English lecturers, and 6 alumni of English and literature study program Sawerigading University Makassar.

\section{RESEARCH DESIGN}

Research and Development (R\&D) design was used to conduct this study. It was aimed at describing the decision making process during the development of a product/program in order to improve the product/program being developed and the developers' capabilities to create things of this 
kind in future situations (Van Den Akker, 1999). Therefore, descriptive approach was employed in this development study.

\section{INSTRUMENTS}

This study used questionnaires and interviews. The questionnaires contained questions divided into five main sections i.e. Background Information, Abilities, Problems, Priorities, and Attitudes. Semistructured interviews were used for cross checking the data derived from the questionnaires about the students' language skills, topics, and language functions.

\section{RESEARCH PROCEDURES}

This research was carried out by implementing three necessary steps i.e.

\section{The Input Step}

In this step, two important decisions were made i.e. to determine the participants and to obtain data on linguistic and learning needs.

Linguistic needs include:

- Recognizing learning abilities

- Identifying learning priorities

Learning needs include:

- Identifying learning problems

- Identifying learning attitudes (styles and preferences)

\section{The Development Step}

This step compiled the overall needs inventory of both linguistic and learning needs. The needs inventory was then used for

- Formulating learning goals

- Outlining the content of the materials

- Selecting the contents and determining relevant tasks

\section{The Output Step}

This step was carried out to design the ELT teaching materials for speaking 1 course. The design stage examined two dimensions of course development i.e.

- Incorporating contents and activities in a lesson plan

- Developing the prototype ELT materials for speaking 1 course

\section{DATA ANALYSIS}

The data derived from the questionnaires were analyzed by using frequency (how often something occurs) and average (mean score) which were included in three categories i.e. the proficiency, the importance, and the frequency level. The proficiency score, the importance score, and the frequency score of linguistic needs and learning needs were derived from giving scores ranging between 1 and 4 to all categories.

\begin{tabular}{|c|l|l|l|}
\hline Scores & $\begin{array}{c}\text { Proficiency } \\
\text { level }\end{array}$ & $\begin{array}{c}\text { Importance } \\
\text { level }\end{array}$ & $\begin{array}{c}\text { Frequency } \\
\text { level }\end{array}$ \\
\hline 1 & Poor & Not important & Hardly ever \\
\hline 2 & Fair & Less important & Seldom \\
\hline 3 & Good & Important & Often \\
\hline 4 & Excellent & Very important & Always \\
\hline
\end{tabular}

The data were then presented in frequency and percentage tables. To calculate frequency, the number of respondents is multiplied with its scores and then divided by the number of respondents in all categories. On the other hand, the mean scores were calculated by:

1. Multiplying the score category with frequency.

2. Adding up all the scores.

3. Dividing by the population

The mean scores of the participants' perceptions were then described by using the following scale: 
1. Refers to $0-1.50$

2. Refers to $1.15-2.50$

3. Refers to $2.51-3.50$

4. Refers to $3.51-4.00$

The results of the data processing revealed the needs inventory required to develop teaching materials. Besides, the data from interviews were qualitatively analyzed with interpretations and in depth discussions.

\section{FINDINGS AND DISCUSSION}

\section{THE INPUT STEP: CARRYING OUT THE NEEDS ANALYSIS}

The needs analysis resulted in the needs inventory derived of linguistic needs and learning needs.

\section{THE INVENTORY OF LINGUISTIC NEEDS}

This type of inventory comprised of the students' learning abilities and learning priorities. To recognize the learning abilities, the students were asked to rate their own vocabulary, pronunciation, and grammar by choosing one of four possible options that suited to their current proficiency level. To identify the learning priorities, the respondents were required to rate the importance level of the three elements of speaking skills. The rating results were then used to determine and to prioritize the components of speaking skills necessary for developing the teaching materials.

\section{LEARNING ABILITIES}

Our results highlighted that the students' proficiency in the speaking components reached 'poor' and 'fair' level. The students' proficiency in grammar was on poor (1.44), pronunciation was on fair (1.63), and vocabulary was on fair as well (1.7).

The results suggested that the students' proficiency level in speaking needs improvement since the poor and the fair indicated low degree or unsatisfactory situation. According to the students, grammar was felt low due to their tendency to have less attention to grammar in speaking courses. Most of them were of the opinion that learning grammar was an obstacle for fluency in speaking (as stated by student 13 in the interview). However, the student's statement might not be interpreted as an effort to ignore grammar entirely in the course of speaking, but this could serve as a good input for the lecturers or the materials developers in order to give more priority over vocabulary and pronunciation than grammar in the speaking courses. Wilkins (1976) is of the opinion that people could describe few things without grammar, but they could express nothing without vocabulary. In addition to vocabulary, Fangzhi (1998) states that it is important to pay attention to pronunciation as well since it results in whether or not someone's message can be passed or not by other people. Therefore, good pronunciation should be one of the first things that students need when learning English.

Conclusively, the results from this study reveal valuable information regarding some fundamental components in developing the teaching materials for speaking courses i.e.

- Vocabulary and pronunciation are very important for speaking courses. This level of importance is assumed based on the average score achieved by the two components (vocabulary achieves 3.93 and pronunciation achieves 3.80). This information leads the lecturers or the materials developers to give the first priority to vocabulary item and pronunciation drill.

- Besides, the data show that grammar achieves 3.45 (important). It indicates that grammar cannot be totally ignored in the teaching materials for speaking courses. However, its portion has to be smaller than the other two components and presented at the end of a unit. 


\section{Learning Priorities}

The data indicated that the materials developers need to give the first priority to vocabulary item (3.93 means very important), the second to pronunciation drill (3.80 means very important), and the last to grammar rules (3.45 means important).

As for the respondents, learning vocabulary is a very important item for learning speaking. It is even considered as the foundation for speaking skills. Even if the students have proper understanding of English grammar, they will not be able to speak without having large vocabulary (stated by student 11 in the interview). Therefore, we can clearly understand that vocabulary is central to English language skills particularly speaking because those who are rich in vocabulary can speak and understand English well. It stands to reason that most respondents believe the more vocabulary they acquire the better speaking skills they will have.

In terms of pronunciation, most respondents think that it is also very important to learn. Pronunciation as an inseparable aspect of the language which has a great influence on students' language intelligibility in communication. Therefore, it is essential that the students learn good pronunciation because it makes a conversation more comfortable for both the speaker and the listener and even helps to avoid misunderstanding (Machackova, 2012)

1. What makes a home? $(3.55$ = very important)

2. A healthy breakfast $(3.53=$ very important $)$

3. What time is it? $(3.51=$ very important $)$

4. Around town $(3.48=$ important $)$

5. Getting to know you $(3.48=$ important $)$

6. Housework $(3.48=$ important $)$

7. What are they doing? $(3.45=$ important $)$

8. Going Shopping $(3.34=$ important $)$

9. My favorite things $(3.32=$ important $)$

10. What are they wearing? $(3.31=$ important $)$

11. My leisure time activities $(3.29=$ important $)$

12. Family tree $(3.28=$ important $)$
With regard to grammar, the respondents gave it an average score of 3.45 which means 'important'. Some researchers have provided support to grammar in teaching English. For example, Priya S.P. (2015), she claims that when we start learning a language, it is important to learn some basic grammar because learning grammar gives knowledge of putting words together in a sensible order. Hence, learning grammar is absolutely inevitable because grammar is the form of language, and words and phrases are the content. If there is no form, there is no content. This fact requires students to use correct grammar that other people can easily understand their English. Without using proper grammar, people are actually just mumbling words with no connection or order. Nonetheless, many students consider that grammar should be the last priority given in the speaking course because grammar will become an obstacle for their speaking skills particularly for those who are novice in English. So, the essential thing about speaking is to practice communicating messages at first and then to learn grammar later after being able to communicate (stated by student 23 in the interview).

As a result, grammar is given a smaller portion than vocabulary and pronunciation in the speaking 1 course. It is taught by using deductive approach (a general rule is given, which is then applied to specific language examples and honed through practice exercises).

\section{Using Real Life Topics to Learn Vocabulary and Pronunciation}

We did an analysis of the importance of learning vocabulary and pronunciation using real life topics. The aim of the analysis was to find out reliable sources of learning vocabulary and pronunciation. The results revealed

that most respondents much preferred to learn about vocabulary and pronunciation by using real life topics (3.51 means very important). For the reason, twenty real life topics were offered for selection. The selected topics were presented as follows. 
Important real life topics of speaking 1 course

The selected topics should be covered for developing the speaking 1 course that the students may learn about speaking skills with a large vocabulary and pronunciation drills of real life topics to fit for the most necessary, relevant and frequent used vocabulary. This decision can be an effective strategy for helping the students in enriching their vocabulary logically, comprehensively and intensively.

\section{Learning English Grammar}

For many students, grammar is often felt insignificant when learning speaking skills since it is presumed to prevent them from being able to speak fluently. Nevertheless, this does not mean that the teachers should overlook it when teaching speaking skills. Understanding grammar rules is important to help the students to speak English effectively. According to Blaxell, R (2012), grammatical structures best support communication and allow for the speaker to more clearly and accurately express ideas. Hence, several grammar items were given to be selected which come up with the following results:

\begin{tabular}{|c|c|c|}
\hline $\begin{array}{l}\text { Grammar } \\
\text { Topic }\end{array}$ & $\begin{array}{c}\text { Importance } \\
\text { level }\end{array}$ & $\begin{array}{c}\text { Number of } \\
\text { Meetings }\end{array}$ \\
\hline 1. There is.... There are ... & $3.55=$ very important & 1 meeting \\
\hline 2. Subject \& Object pronouns & $3.51=$ very important & 1 meeting \\
\hline 3. Possessive adjectives & $3.50=$ important & 1 meeting \\
\hline $\begin{array}{l}\text { 4. Countable and uncountable } \\
\text { nouns } 1\end{array}$ & $3.50=$ important & 1 meeting \\
\hline 5. Am, is, are & $3.50=$ important & 3 meeting \\
\hline 6. Present continuous & $3.48=$ important & 2 meeting \\
\hline 7. Present simple & $3.48=$ important & 3 meeting \\
\hline 8. Preposition of place & $3.46=$ important & 1 meeting \\
\hline Total & & 12 meetings \\
\hline
\end{tabular}

\section{THE LEARNING NEEDS INVENTORY}

Learning needs refer to the students' learning problems and learning attitudes. Both types of information were essential to fully understand strategies and methods that might be the most effective for teaching speaking 1 skills, which were used not only for minimizing the effect on the learning problems, but also for achieving more desirable learning outcomes.

\section{LEARNING PROBLEMS}

Learning problems were identified based on the analysis of the respondents' perceptions of some obstacles encountered by the students in learning speaking skills. The students at least encounter four problems as they learn in speaking course i.e.

a. Psychological problem: the students feel shy speaking English (2.74) because they are afraid to make errors (3.04) and afraid to be criticized by teachers and other students due to the errors (3),

b. Mother tongue interference: the students often use their native language when they should speak English in the classroom (3.09),

c. Limited knowledge of the topic: the students don't have background information and vocabulary to talk about discussed topics (2.99),

d. Limited linguistic resources e.g. limited vocabulary (3.06), bad pronunciation (3.03), and bad grammar (3.25), which causes the students are unable to speak English effectively.

The learning problems are considered 'often occur' because they have scores ranging between 2.74 and 3.25. The problems are significant inputs to the teachers or the course designers to take immediate actions to reduce negative impacts of the problems by selecting the most effective methods, and strategies for teaching as possible solutions. For example, when a teacher knows that his students' greatest problem in speaking is shyness, then the teacher can select a technique of participative exercise game which allows the students to use very basic and familiar phrases to be practiced in a game. This technique is used for encouraging the students to learn in a relax and joyful learning situation which is very effective to build the students' confidence and to convince them that speaking English is a joyful activity. When the 
teacher sees that the students get used to speaking in English with the basic phrases technique, he is then ready to move on giving more complex ideas to the students gradually. With regard to this, Davis (1997) in Westwood (2008) suggests that the design and selection of teaching methods must take into account not only the nature of the subject matter but also how students learn. How students learn might be interpreted as problems encountered and styles used by the students in learning.

\section{LEARNING ATTITUDES}

An attitude is analyzed to obtain information about how well the students like studying in a program (Brown, 1995). It may be gained by identifying the students' learning preferences and styles. Learning preferences refer to the way the students tend to learn. While, learning styles refer to educational environments under which the students are most likely to learn.

\section{Learning Preferences}

Learning preferences are presented based on the participants' perceptions of how the students should learn vocabulary item and pronunciation drills. The students' learning preferences over vocabulary i.e. using vocabulary to communicate (3.86), learning vocabulary in conversations (3.70), listening and repeating vocabulary (3.63), learning vocabulary in real life topics (3.55). The four possible ways of vocabulary learning preferences should be considered for selection as strategies for teaching vocabulary in speaking 1 course.

In addition, the students' learning preferences over pronunciation in speaking 1 is to learn pronunciation from native English speakers' voice recording (3.81). Linge (2015) deems that one of the most powerful ways of learning pronunciation is mimicking native speakers. This can be a good strategy to improve the students' pronunciation as they can focus on listening how to say things correctly and simply try to mimic the recordings as closely as they can. Thus, it is strongly suggested for using the voice recordings of native speakers of English as a coherent strategy for teaching pronunciation in speaking 1 course.

\section{Learning Styles}

The findings from this study confirm that the students' learning styles are identified as communicative and concrete learners because the students' learning styles are fit in type to the characteristics of the four learning styles. The data show that the students have distinctive styles in learning speaking 1 course i.e. talking to friends in English (3.84), learning by games (3.76), using films and videos (3.71), talking in pairs (3.64), using pictures (3.58), speaking in small groups (3.56), and interacting in role plays (3.54). Accordingly, the learning styles should be adjusted to select effective teaching styles, methods and course organization which can result in improved learners' satisfaction and attainment (Willing, 1988).

In sum, the needs analysis carried out to develop the speaking 1 course has resulted in:

1. Recognizing the students' learning ability to speak English

2. Discovering the language components which are really needed learning as priority over the course

3. Selecting the real life topics and basic grammar rules which are much preferred by the students

4. Identifying the problems which are frequently encountered by the students.

5. Finding the learning preferences and the learning styles that are much preferred by thestudents.

\section{THE DEVELOPMENT STEP: USING THE NEEDS INVENTORY}

The needs inventory found in the needs analysis were then used for formulating learning aims and objectives in the Development Step.

\section{FORMULATING LEARNING AIMS AND OBJECTIVES}

Aims and objectives were formulated on the basis of the needs inventory as the foundation for developing course materials. The teaching materials 
were specifically designed for fulfilling two course aims i.e.

- To help students to communicate effectively and confidently in English by developing the students' vocabulary, pronunciation, and basic grammar,

- To provide a good foundation for speaking which enables students to communicate everyday situations and topics.

The two course aims were then broken down into smaller goals of learning known as the course objectives. Here are the examples:

a. Students are able to practice common expressions of greeting and farewell when meeting other people, to introduce themselves and others, as well as to get and give personal information in informal situations.

b. Students are able to talk about their families using vocabulary for family members, able to ask simple questions for requesting information about family members, as well as able to describe and illustrate family members.

c. Students are able to use appropriate expressions and vocabulary to tell the time and ask the time in English.

In short, the formulation of aims and objectives not only provides information on measurable outcomes of the teaching materials, but also facilitates the preparation and the organization of the teaching materials.

\section{SELECTING THE COURSE CONTENTS}

The course contents were selected from the major topics and arranged in a logical order as they would be presented in the classroom. The needs analysis contributed a list of discussion topics, needed vocabularies and suitable grammar as shown earlier in tables. However, the list was refined into selection. The selection process took place by considering the course's aims and objectives, the importance of the selected topics, the students' knowledge, the allocated

\section{6}

EDUVELOP

Journal of English Education and Development

Universitas Sulawesi Barat time to teach the topics, as well as consultation with teachers. As Richards (2001) states that information gathered during needs analysis contributes to the planning of course content.

After consultation with the English lecturers at the English department Sawerigading University, all of the twelve topics were finally selected to be the main topics in Speaking 1 course discussion materials as well as appropriate vocabulary and grammar topic at each meeting. The consultation discusses how and why the topic, vocabulary, and grammar should be arranged in such a way as to produce the following content.

\begin{tabular}{|r|l|l|l|}
\hline $\begin{array}{r}\text { Prad } \\
\text { tice }\end{array}$ & $\begin{array}{l}\text { Vocabulary and } \\
\text { pronunciation }\end{array}$ & Speaking Topic & Grammar Material \\
\hline 1 & Personal identities & Getting to know you & Am, is, are (+) \\
\hline 2 & Family members & Family tree & am, is, are (-\&?) \\
\hline 3 & Hobbies & My Favorite things & Subject \& Object \\
\hline 4 & Food and beverages & A healthy breakfast & Possessive adjectives \\
\hline 5 & Things at home & What makes a home? & There is, there are \\
\hline 6 & Products \& Prices & Going Shopping & Nouns and numbers \\
\hline 7 & Verbs-ing & What are they doing & Present Cont. $(+)$ \\
\hline 8 & Clothes & What are they wearing & Present Cont. (-\&?) \\
\hline 9 & Time \& daily routine & What time is it? & Simple Present (+) \\
\hline 10 & Household chores & Housework & Simple Present (-) \\
\hline 11 & Free time activities & My leisure time activities & Simple Present (?) \\
\hline 12 & Public places & Around town & Pref. of Places \\
\hline
\end{tabular}

The decision about sequencing the course contents is taken on the basis of 'need' criteria because the topics are arranged in order of importance to the students' needs in personal and social lives Richards (2001). Besides, the topics need to be sequenced in order of logical relationships from one to the other topics according to a theme or storyline (stated by a lecturer in the interview). The logical sequence of the topics was then linked to the vocabularies and grammar rules to be taught and practiced altogether in the classroom interactions.

\section{THE OUTPUT STEP: DESIGNING ELT MATERIALS}

Design refers to the realization of the concept of needs analysis-based teaching materials into actual 
productions of teaching materials i.e. making lesson plans and prototypes of ELT materials or creating a handbook for 1 unit subject.

\section{PREPARING LESSON PLANS}

Three lesson plans for three units were developed for the speaking 1 course. The each lesson plan consisted of ten essential elements i.e. 1) Subject name, 2) Unit, 3) Topic, 4) Time, 5) Course description (aims), 6) Course Objectives, 7) Materials and equipment, 8) Procedures, 9) Evaluation, and 10) Extra- class work. In pedagogical perspective, a lesson plan in a language program functions to identify the learning destination (objective of a lesson) and to mark out the route (activities for each stage of the lesson). It is an aid for a teacher to plan his/her teaching methodologies and strategies effectively. Therefore, a well-prepared teacher should write down the details of each activity in the form of lesson plans which will guide the interactions between teacher and students in implementing how detailed a lesson plan needs to be. Formulating the plan for teaching will keep both the teacher and the learner focused on where they are going, how they are going to get there, and what to achieve when they arrive.

\section{DEVELOPING THE PROTOTYPES OF ELT MATERIALS}

Three prototypes were developed based on the prepared lesson plans. The prototypes of ELT materials refer to the first model of English teaching materials, from which other forms of are copied or developed. The organizational structures of the teaching materials of are developed by units. Each unit represents a topic and the topic consists of three lessons i.e. Lesson A: Skill Getting, Lesson B: Skill Using, and Lesson C: Review.

Lesson A: Skill Getting is aimed at preparing and equipping the students with specific elements of knowledge which compose communicative ability for later communication. Therefore, this lesson presents knowledge of linguistic forms that the students need to be able to speak English in a certain topic such as vocabulary and pronunciation drills. After the students are equipped with the linguistic forms, they have to take a part in pair practice which is aimed at linking between the language forms (vocabulary and pronunciation) and their potential for real communications.

In addition, lesson B: Skill Using makes effort to bridge the gap between the students' knowledge of linguistic forms and their ability to talk about a particular topic. There are two sub activities in this lesson i.e. functional communication and social interaction activities. Functional communication activity shows how the vocabulary and expressions are used in casual conversation. This lesson gives a particular real life situation with specific language structure, vocabulary, as well as pronunciation to help the students talk about a particular topic. Besides, social interaction activity gives the students opportunity to use their knowledge of linguistics forms in a half dialogue role play. This lesson enables the students to be involved in a social interaction of a particular topic by using the previous equipped language forms.

On the other hand, lesson C: Review is aimed at measuring how much the students have learnt in a given unit. This lesson provides three sub activities i.e. language game, grammar presentation, and extra class work. Language game requires the students to show off their language creativity in speaking naturallyand enable them to interact spontaneously in a conversation. Grammar presentation is given to help the students understand a particular language form that they have used in the previous communicative activities e.g. in pair practice, functional communication activities. The teacher needs to focus on explaining a particular rule of a language structure and evaluates all the students have learnt by giving extra class work that is written grammar exercises to do at home.

\section{CONCLUSIONS}

We have here described a needs analysis that is considered appropriate to develop the teaching 
materials for speaking 1 course. We found three important things from the implementation of the needs analysis i.e. The first; significant information on what to teach and how to teach the speaking 1 course. The information on what to teach is derived from the needs inventory of the students linguistic needs (learning abilities and priorities), while the information on how to teach is derived from the needs inventory of the students learning needs (learning problems and learning attitudes). The second; three necessary steps which describe how to design a needs analysis based ELT materials. The third; the prototype of ELT Materials for speaking 1 course which reflects the contents of a well-developed course materials based on a needs analysis. Therefore, we believe that the findings could be applied quite reliably in developing welldesigned teaching materials for other units of speaking 1 course. However, further studies are still needed to determine two things i.e. Firstly, if these findings could bring about a positive effect on the students' progress in speaking English. Secondly, if these findings could be used for developing teaching materials for other English courses e.g. reading, writing, and listening.

\section{REFERENCES}

Aladdin, A. (2016). A Needs Analysis for the Course Materials Design of the Arabic Language Course, International Journal of Social Science and Humanity, $6(6), 423-426$.

Alwasilah, C. (2007). Redesigning Indonesian Course in the undergraduate curriculum: The Indonesian case. Paper presented at ASAIHIL Conference, Lingnan University, Hong Kong, April 12, 2007.

Blaxell, R. (2012). Can we use Grammar to Support Students' Communication Skills?. eCULTURE, 5(1). Retrieved from http: //ro.ecu.edu.au/eculture/vol5/ iss $1 / 5$

Brown, J. D. (1995). The Elements of Language Curriculum; A Systematic Approach to Program Development. Boston: Heinle\&Heinle Publishers.

Engelmann, S. (1993). The Curriculum as the Cause of Failure, Oregon Conference Monograph Journal 5(2), 3-8.
Fangzhi, C. (1998). The teaching of pronunciation to Chinese students of English. English Teaching Forum, 36 (1), 37-39.

Jeong, Myeonggi, \& Kim, Jeongryeol. (2012). Needs Analysis and Development of Teaching Materials for Elementary English Underachievers. English Teaching, 67(3), 365-394.

Linge, O. (2015, February 18). 24 Great Resources for Improving Your Mandarin Pronunciation. Retrieved from http://www.hackingchinese.com

Lowenberg, Peter H. 1991. English As An Additional Language In Indonesia. World Englishes, 10/2, 127138.

Machackova, E. (2012). Teaching English Pronunciation to Secondary School Students. (Unpublished thesis), Department of English Language and Literature, Faculty of Education, Masaryk University Brno, Czech Republic.

Paradowski, M. B. (2002). Needs Analysis as The First Step in Syllabus Design, Retrieved from http:// publikacje.ils.uw.edu.pl/publication/view

Priya S.P. (2015). The Importance of Teaching Grammar More Interestingly in the Classrooms. International Journal of English Language, Literature and Translation Studies, 2 (3), 447-449.

Ratnah (2013). Developing English For Specific Purpose (ESP) Course for Tour and Travel Students Based on Needs Analysis. (Unpublished dissertation), Post Graduate program, State University of Makassar.

Richard, J.C. (2001). Curriculum Development in Language Teaching. Cambridge University Press: United Kingdom.

Saragih, E. 2014. Designing ESP Materials for Nursing Students Based On Needs Analysis, International Journal of Linguistics, Macrothink Institute, 6 (4), 5970.

Van den Akker, J. (1999). Principles and Methods of Development Research. Kluwer Netherlands: Academic Publishers

Wilkins, D. A. (1979). Notional Syllabuses. Oxford: Oxford University Press.

Willing, K. (1988). Learning Styles in Adult Migrant Education. Australia: NCRC Research Series. 